\title{
PENGARUH LEADERSHIP STYLE TERHADAP MANAGEMENT CONTROL SYSTEM DENGAN TEKNOLOGI INFORMASI DAN ORGANIZATIONAL CULTURE SEBAGAI VARIABEL MEDIASI PADA UMKM SEKTOR GARMEN STUDI KASUS DI KABUPATEN GRESIK
}

\author{
Widhi Ariestianti R. ${ }^{*}$, Hatane Samuel ${ }^{2}$ \\ ${ }^{1}$ STIESIA Surabaya \\ ${ }^{2}$ Fakultas Ekonomi UK Petra Surabaya \\ Email: Widhi_rochdianingrum@yahoo.co.id; samy@peter.petra.ac.id \\ * Penulis korespondensi
}

\begin{abstract}
Abstrak: Penelitian ini membahas pengaruh leadership style terhadap management control system dengan teknologi informasi dan organizational culture sebagai variabel mediasi. Objek penelitian ini adalah UMKM sektor garmen yang ada di Kabupaten Gresik. Tujuan dari penelitian ini untuk mengetahui apakah leadership style dapat secara langsung mempengaruhi management control systemUMKM sektor garmen yang ada di Kabupaten Gresik serta apakah variabel teknologi informasi dan organizational culture dapat memediasi pengaruh leadership style terhadap management control system. Metode penelitian yang digunakan adalah SEM (Structure Equation Model). Hasil penelitian ini menunjukkan bahwa leadership style tidak berpengaruh secara langsung terhadap managemen control system, namun leadership style dapat mempengaruhi management control system melalui variabel mediasi teknologi informasi dan organizational culture. Teknologi informasi yang digunakan tidak berpengaruh terhadap organizational culture.
\end{abstract}

Kata kunci: Leadership style, teknologi informasi, organizational culture, management control system.

\begin{abstract}
The issue of the influence of the leadership style on management control system with information technology and organizational culture as a moderating variable. The object of this study is the garment sector SMEs in Gresik. The purpose of this study to determine whether the leadership style can directly affect the management control system SME garment sectors in Gresik and whether the variable information technology and organizational culture may mediation the influence of the leadership style of management control system. The method used is the SEM ( Structure Equation Model). The results of this study indicate that leadership style has no direct influence on the management control system, but can affect the leadership style of management control system through information technology and organizational culture moderating variable. Information technology used does not affect the organizational culture.
\end{abstract}

Keywords: Leadership style, information technology, organizational culture, management control system

\section{PENDAHULUAN}

Era perdagangan bebas menuntut semua sektor usaha termasuk UMKM berada pada kondisi pasar yang kompetitif. Agar dapat bertahan diperlukan penyesuaian terhadap tujuan yang ingin dicapai dan strategi yang digunakan. Management control system (MCS) merupakan sebuah alat manajemen yang mampu membuat pemimpin suatu organisasi mengikuti strategi formal yang efektif sehingga tujuan yang ingin dicapai dapat diwujudkan.

Penerapan management control system dalam suatu organisasi sangat bergantung dengan leadership style dalam organisasi tersebut. Pemimpin dengan transactional leadership style lebih eksplisit dalam menetapkan standar yang harus dijalankan, pengukuran kinerja karyawan serta sistem pembagian kerja. Pemimpin dengan transformational leadership style, semua pengambilan keputusan dilakukan oleh top management, penentuan besarnya target yang harus didapatkan sifatnya jelas namun pengukuran kinerja terhadap target yang diharapkan tidak digambarkan secara rinci dan jelas (E Pieter Jansen; 2008). Penggunaan teknologi informasi mempunyai efek yang signifikan pada penerapan managemen kontrol suatu organisasi (Hasan, Abdellah, dan Ameen; 2011). Semakin canggih teknologi informasi yang digunakan maka semakin canggih management control system yang diterapkan (Hussain, Mostaq, dan Louis; 2012). Keputusan penggunaan tekolonogi informasi suatu organisasi sangat bergantung pada pemimpin organisasi tersebut (Bruque dan Moyano, 2007; Nguyen, 2009). Pemimpin dengan transformational leadership style secara positif mempengaruhi penggunaan teknologi informasi dalam organisasi tersebut danpemimpin dengan transactional leadership style tidak mempuyai pengaruh yang signifikan dalam penggunaan teknologi informasi pada suatu organisasi (Jeroen, Martin, dan Ko de Ruyter; 200). Penggunaan teknologi informasi pada organisasi dapat menumbuhkan rasa berbagi antar anggota organisasi serta dapat menyampaikan pandangan umum yang dapat men- 
jadi nilai dan budaya dalam organisasi tersebut (Enrique, Juan, M.Reyes, dan Jose, 2001). Budaya organisasi memainkan peran yang penting dalam penerapan management control system (Hendri; 2006). Budaya dalam organisasi sangat dipengruhi oleh pemimpin dalam organisasi. Pemimpin dengan transformational leadership style dan transactional leadership sytle memiliki suatu hubungan yang positif dengan clan dan adhocracy culture.

Pada tahun 2010 ketika Indonesia memasuki pasar China Asean Free Trade, banyak pelaku usaha termasuk pelaku usaha mikro kecil menengah khawatir tidak dapat bersaing dengan barang-barang yang didatangkan dari luar negeri. Hal ini dikarenakan harga barang dari luar negeri lebih terjangkau. UMKM sektor garmen yang ada di kabupaten Gresik termasuk salah satu sektor UMKM terbesar setelah UMKM makanan ringan dan merupakan salah satu UMKM yang dapat bertahan dan bersaing pada era pasar bebas saat ini. Keberhasilan bertahannya UMKM sektor garmen didukung dengan management control system yang diterapkan. Penerapan management control system pada UMKM sektor garmen sifatnya masih sederhana. Penggunaan teknologi informasi sebagian besar digunakan sebagai media komunikasi dengan rekan bisnis. Budaya yang ada dalam organisasi merupakan budaya patrealistik yang menekankan pada kekeluargaan, kontrol ketat terhadap out put yang dihasilkan, dan kestabilan dalam menjalankan usaha. Pada UMKM sektor garmen walaupun pemimpin tidak melakukan kontrol secara langsung setiap hari, proses bisnis dapat berjalan dengan baik. Hal ini dikarenakan pemilik memiliki orang kepercayaan dalam menjalankan bisnisnya, serta adanya rasa hormat dan segan karyawan kepada pemimpin atau pemilik UMKM sekror garmen tersebut.

Dalam penjabaran hasil penelitian terdahulu, diketahui bahwa management control system dipengaruhi oleh gaya kepemimpinan, teknologi informasi yang digunakan dan budaya dalam organisasi tersebut. Oleh karena itu dalam penelitian ingin diketahui apakah hal-hal tersebut (gaya kepemimpinan, teknologi infromasi, dan budaya organisasi) walaupun sifatnya masih sederhana mempengaruhi management control system yang ada di UMKM sektor garmen di Kabupaten Gresik.

\section{KAJIAN TEORI DAN HIPOTESIS}

\section{Management control system}

Merupakan suatu proses dimana manager memastikan bahwa sumber daya yang dimiliki organi- sasi telah digunakan secara efektif dan efisien dalam mencapai tujuan yang diinginkan (Langfield dan Smith, 1997). Kerangka kerja leverage of control Simon (1995) menekankan peran management control system bagi organisasi yang mengalami perubahan. Leverage of control Simon terdiri atas empat dimensi (Toumas, 2009) yaitu (a) belief system merupakan sistem yang digunakan untuk meningkatkan nilai yang berkaitan dengan strategi bisnis serta mencari peluang-peluang lain dalam satu nilai bisnis yang sama (b) boundary system merupakan sistem yang digunakan untuk meminimaliasasi resiko yang dihadapi oleh organisasi (c) diagnostic control system merupakan feedback yang sifatnya formal dan digunakan untuk mengotrol outcomesuatu organisasi (d) interactive control system merupakan sistem yang digunakan sebagi signalpada semua tingkat organisasi untuk dilakukan kontrol.

\section{Organizational culture}

Didefinisikan berdasarkan competing value framework yang dikembangkan oleh Quinn dan rekan (Cameron \& Quinn, 1999; Quin, 1998; Quin dan Rohrbaugh, 1983). Competing value framework didasarkan pada analisis empiris nilai suatu individu dalam organisasi mengenai kinerja dan perilaku yang dapat digunakan untuk membangun sebuah budaya organisasi (Berrio, 2003). Competing value framework merupakan sebuah kerangka kerja yang dapat memberikan penjelasan hubungan karakteristik budaya suatu organisasi dengan efektifitas dan kesuksesan (Qomar Ali dan Manqoosh Ur Rehman, 2011). Model competing value framework yang terdiri atas empat nilai yang berbeda dan bersesuaian dengan empat jenis tipe budaya organisasi (Kim Cameron dan Robert Quinn, 2010) yaitu (a) clan lingkungan kerja merupakan tempat kerja yang sangat menyenangkan, anggota organisasi saling berbagi informasi yang sifatnya personal, dan lingkungan kerja seperti keluarga sendiri (b) adhocracy menggambarkan lingkungan kerja yang dinamis, entrepreneurial, dan tempat yang kreatif untuk bekerja (c) market menggambarkan lingkungan kerja yang berorientasi pada hasil dan perhatian utama tertuju pada pekerjaan yang selesai dilakukan (d) hierarchy menggambarkan lingkungan kerja yang sangat formal dan terstruktur. Pengukuran organizational culture menggunakan instrument organizational culture assessment instrument (OCAI), kriteria pada OCAI digunakan untuk menghasilkan kontur budaya organisasi yang berguna berdasarkan persepsi dan preferensi yang terkait dengan enamsubsistem budaya yaitu (Qomar Ali dan Manqoosh Ur Rehman, 2011) dominant charac- 
teristic; organizational leadership; management of employee; organization glue; strategic emphases; dan criteria of success.

\section{Teknologi Informasi}

Didefinisikan sebagai kapabilitas yang ditawarkan kepada organisasi melalui komputer, software, telekomunikasi untuk mengirim data, pengetahuan, proses, dan inovasi pada setiap individu yang ada dalam organisasi (Morteza, Mohammad, Tang, Norzima. 2011). Teknologi informasi yang diadopsi untuk usaha kecil menengah merupakan aplikasi dari hardware dan software yang menyediakan jalan keluar untuk menyelesaikan masalah guna mendukung proses pengambilan keputusan, operasional, dan manajemen dalam usaha kecil menengah tersebut (Thong dan Yap; 1995).

\section{Leadership Style}

Literatur kontemporer berfokus pada dua jenis gaya kepemimpinan yaitu transformational leadership dan transactional leadership.Transformational leadership adalah pemimpin yang lebih menekankan pada peningkatan moral dan memotivasi para karyawan (Bass,1999). Transformasional leadership terdiri atas empat dimensi yaitu (Bass dan Avolio; 1994) (a) idealized influence, pemimpin dapat menumbuhkan rasa kagum, rasa hormat, dan kepercayaankaryawan terhadap diri pemimpin (b) inspirational motivation, pemimpin memberikan tantangan untuk karyawan dan memberikan makna terhadap setiap yang dikerjakan. (c) intellectual stimulation, pemimpin mengajak karyawan untuk mengembangkan ide baru; mencari penyelesaian masalah dengan cara yang kreatif;dan mengembangkan suatu cara atau pemikiran baru dalam dalam bekerja (d) individualize consideration, pemimpin mendengarkan secara aktif dan memberikan perhatian yang khusus pada pencapaian yang didapatkan oleh karyawan dan kebutuhan karyawan agar karyawan dapat terus berkembang. Transactional leadership memenuhi keinginan para karyawan berdasarkan rasa ketertarikan karyawan itu sendiri (Bass, 1999). Transactional leadership terdiri atas tiga dimensi (Bass; 1990) yaitu (a) contingen reaward, pemimpin yang akan memberikan reward atau punishment berdasarkan upaya yang telah dilakukan oleh karyawan (b) management by exception, pemimpin menjelaskan apa yang perlu dilakukan dalam pekerjaan tersebut dan hal-hal berkaitan langsung dengan standar kinerja. Terdapat dua karakteristik management by exception yaitu management by exception active danmanagement by exception passive (c) laissez-faire leadership, pemimpin melepaskan tanggung jawabnya sebagai pemimpin dan melakukan penghindaran dalam pengambilan keputusan (Bass, 1998).

\section{Hipotesis penelitian}

Leadership style memilikiperan penting pada sistem kontrol suatu organisasi. Perubahan leadership style dari transformasional leadership menjadi transactional leadership mengakibatkan perubahan sistem kontrol dari yang sifatnya implisit menjadi lebih eksplisit (E.Pieter Jansen; 2008). Berdasarkan penelitian E.Pieter Jansen dapat ditarik suatu hipotesis pertama:

$\mathrm{H}_{1}$ : Leadership style berpengaruh terhadap management control system.

Penggunaan tekolonogi informasi suatu organisasi bergantung pada pemimpin organisasi tersebut (Bruque dan Moyano, 2007; Nguyen, 2009). Transformasional leadership style berpengaruh signifikan secara positif terhadap penerimaan teknologi sedangkan transactional leadershipstyle tidak menunjukkan efek yang signifikan terhadap penerimaan teknologi (Jereon, Martin, dan Ko; 2005). Berdasarkan penelitian Jereon, Martin, dan Ko dapat ditarik suatu hipotesiskedua:

$\mathrm{H}_{2}$ : Leadership style berpengaruh terhadap teknologi informasi.

Budaya organisasi berasal dari pemimpin organisasi (Bass dan Avolio, 1993). Transformational leadership style dan transactional leadership style memiliki hubungan yang positif pada clan culture dan adhocracy culture (Leon; 2010). Berdasarkan penelitian Leon dapat dirumuskan suatu hipotesis ketiga:

$\mathrm{H}_{3}$ : Leadership style berpengaruh terhadap organizational culture.

Penggunaan teknologi informasi pada organisasi dapat menumbuhkan rasa berbagi antar anggota organisasi serta dapat menyampaikan pandangan umum yang dapat menjadi nilai dan budaya dalam organisasi tersebut (Enrique, Juan, Reyes, dan Jose; 2001). Berdasarkan penelitian Enrique, Juan Reyes, dan Jose dapat dirumuskan hipotesiskeempat

$\mathrm{H}_{4}$ : Teknologi informasi berpengaruh terhadap organizational culture.

Setiap organisasi mempunyai budaya yang berbeda, sehingga sistem kontrol yang dimiliki juga berbeda. Organizational culture mempunyai efek yang penting dalam management control system 
organisasi (Henri; 2006). Berdasarkan penelitian Henri dapat dirumuskan hipotesis kelima:

$\mathrm{H}_{5}$ : Organizational culture berpengaruh terhadap management control system.

Teknolgi informasi memainkan peran sentral dalam management control system (Hamed, Habibollah, dan Baqer, 2010). Semakin canggih teknologi informasi yang digunakan maka akan semakin canggih pula management control system suatu organisasi (Hasan, Mostaq, dan Louis, 2012). Berdasarkan penelitian Hasan, Mostaq dan Louis dapat dirumuskan hipotesis keenam:

$\mathrm{H}_{6}$ : Teknologi informasi berpengaruh terhadap management control system.

\section{Kerangka Penelitian}

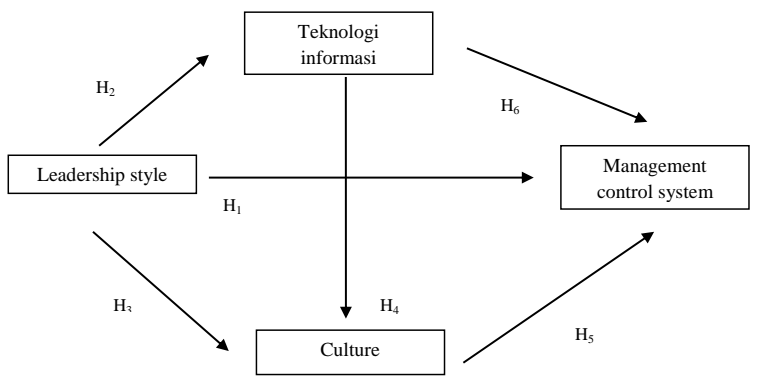

\section{METODE PENELITIAN}

Penelitian ini menggunakan 54 responden yang merupakan pemilik UMKM sektor garmen di Kab. Gresik. UMKM sektor garmen merupakan UMKM yang memproduksi sarung tenun ATM; songkok; batik tulis khas Gresik; kerudung; konfeksi pakaian muslim anak-anak, laki-laki dewasa, wanita dewasa dan mukena. Penelitian ini menggunakan data primer yang didapatkan dengan menyebar kuesioner dengan skala linkert 1-5. Pengukuran variabel organizational culture menggunakan OCAI (organizational culture assessment instrument) yang dikembangkan oleh Kim Cameron dan Robert Quinn (2010). Pengukuran variabel management control systemmenggunakan dimensi interactive control system. Indikator yang digunakan dalam penelitian ini sama dengan indikator yang digunakan dalam penelitian Tubagus Ismail, Lili Sugeng W, Meutia, dan Munawar (2012). Pengukuran variabel leadership style menggunakan multifactor leadership questionare (MLQ) form 6S yang dikembangkan oleh Bernad M Bass dan Bruce J Avolio (1992). Pengukuran variabel teknologi informasi menggunakan indikator yang dikembangkan oleh Milind Kumar Sharma dan Rajat Bhagwat (2006). Untuk menganalisis data yang didapatkan digunakan metode SEM (structure equity model) dengan menggunakan PLS (Partian least square).

\section{PEMBAHASAN}

\section{Analisis convergent validity dan cross loading}

Tabel 1. Convergent validity dan cross loading leadership style

\begin{tabular}{lcc}
\hline \multicolumn{1}{c}{ Keterangan } & $\begin{array}{c}\text { Convergent } \\
\text { validity }\end{array}$ & $\begin{array}{c}\text { Cross } \\
\text { loading }\end{array}$ \\
\hline Contingent reward & 0.816670 & 0.816670 \\
Idealize influence & 0.748393 & 0.748393 \\
Individual consideration & 0.685755 & 0.685755 \\
Inspirational motivation & 0.697842 & 0.697842 \\
Intelrctual stimulation & 0.486387 & 0.486387 \\
Laissez faire leadership & 0.700852 & 0.700852 \\
Management by exception & 0.649284 & 0.649284 \\
\hline
\end{tabular}

Berdasarkan tabel 1 diketahui bahwa dimensi contingen reward memiliki convergent validity yang tinggi. Hal ini digambarkan dengan pemimpin UMKM sektor garmenakan memberikan penghargaan ketika karyawan dapat mencapai target yang diberikan. Dimensi intellectual stimulation memiliki convergent validity yang rendah. Hal ini digambarkan dengan karyawan diberikan kesempatan untuk mempelajari sendiri terlebih dahulu jika terdapat model yang baru yang harus dibuat, jika karyawan tetap merasa kesulitan karyawan akan bertanya kepada pemimpin. Kesempatan dalam menyelesaikan masalah terlebih dahulu terbatas pada cara membuat produk tersebut bukan pada masalah manajemen. Pada variabel leadership style masing-masing dimensi memiliki korelasi yang tinggi pada dimensinya jika dibandingkan dengan koerelasinya pada indikator atau dimensi yang lain sehingga varibel leadership style memiliki discriminant validity yang tinggi.

Tabel 2. Convergent validity dan cross loading management control system

\begin{tabular}{lcc}
\hline \multicolumn{1}{c}{ Keterangan } & $\begin{array}{c}\text { Convergent } \\
\text { validity }\end{array}$ & $\begin{array}{c}\text { Cross } \\
\text { loading }\end{array}$ \\
\hline $\begin{array}{l}\text { Tercipta diskusi ketika terjadi per- } \\
\text { temuan antara pemimpin, } \\
\text { karyawan dan rekan sejawat } \\
\text { (MCS1) }\end{array}$ & 0.734646 & 0.734646 \\
\hline $\begin{array}{l}\text { Mencari tantangan baru dan } \\
\text { penambahan kapasitas berdasarkan } \\
\text { data yang ada (MCS2) }\end{array}$ & 0.670563 & 0.670563 \\
\hline $\begin{array}{l}\text { Melakukan dugaan dalam } \\
\text { pengambilan keputusan (MCS3) }\end{array}$ & 0.749850 & 0.749850 \\
\hline $\begin{array}{l}\text { Lanjutan ... } \\
\begin{array}{l}\text { Memberikan gambaran umum } \\
\text { mengenai organisasi (MCS4) }\end{array}\end{array}$ & 0.663214 & 0.663214 \\
\hline $\begin{array}{l}\text { Tercipta komitmen pada organisasi } \\
\text { (MCS5) }\end{array}$ & 0.758232 & 0.758232 \\
\hline
\end{tabular}


Berdasarkan tabel 2 indikator MCS 5 memiliki convergent validity yang tinggi.Hal ini biasanya dikarenakan figure pemilik UMKM sektor garmen. Para pemilik memperlakukan karyawan seperti keluarga sendiri dan karyawan diberikan keleluasaan untuk mengerjakan pekerjaannya. Misalnya karyawan bagian menjahit diperbolehkan mengerjakan pekerjaannya di rumah masing-masing sehingga para karyawan dapat mengerjakan pekerjaannya setelah pekerjaan rumah terselesaikan. Keleluasaaan dalam bekerja yang diberikan oleh pemilik membuat para karyawan merasa nyaman bekerja pada pemilik atau "juragan" dan hal tersebut menimbulkan rasa sungkan karyawan kepada pemilik. Indikator MCS 4 memiliki convergent validity yang rendah. Para pekerja ketika bekerja kepada pemilik UMKM hanya diberikan penjelasan mengenai apa yang harus dikerjakan, berapa lama harus dikerjakan, dan berapa upah yang didapatkan. Pemberian gambaran umum hanya terbatas pada masalah pekerjaan.Pada variable management control system masing-masing indikator memiliki korelasi yang tinggi pada indikatornya jika dibandingkan dengan koerelasinya pada indikator atau dimensi yang lain sehingga variabel management control system memiliki discriminant validity yang tinggi.

Tabel 3. Convergent validity dan cross loading organizational culture

\begin{tabular}{lcc}
\hline \multicolumn{1}{c}{ Keterangan } & $\begin{array}{c}\text { Convergent } \\
\text { validity }\end{array}$ & $\begin{array}{c}\text { Cross } \\
\text { loading }\end{array}$ \\
\hline Managemet of employee & 0.861472 & 0.861472 \\
Organizational leadership & 0.861472 & 0.861472 \\
Strategic emphasis & 0.812772 & 0.812772 \\
Criteria of success & 0.815980 & 0.815980 \\
Dominan organizational & 0.682827 & 0.682827 \\
characteristic & & \\
Organizational glue & 0.755672 & 0.755672 \\
\hline
\end{tabular}

Berdasarkan tabel 3 dapat diketahui bahwa dimensi organizational leadership dan management of employee mempunyai convergent validity dan cross loading tertinggi. Dimensi organizational leadership digambarkan dengan pemimpian dalam UMKM merupakan contoh dalam mengkoordinasi dan mengatur. Pemimpin UMKM mengatur sistem kerja dan melakukan koordinasipada seluruh bagian yang ada dalam UMKM. Dimensi management of employee digambarkan dengan pemimpin menekankan kerjasama dan partisipasi. Hal ini dikarenakan antara bagian yang satu dengan yang lain dalam UMKM sektor garmen saling terkait satu sama lain. Jika salah satu karyawan pada salah satu tahap tidak dapat bekerja sama dengan baik, akan menghambat proses pada tahap tersebut dan proses pada tahap berikutnya. Dimensi yang memiliki convergent validity dan cross laoding yang terendah adalah dominan characteristic. Dimensi dominan organizational characteristic pada UMKM digambarkan dengan budaya organisasi yang bersifat kekeluargaan namun terkontrol karena masih melekatnya budaya patrealistik yang melakat dalam masyarakat. Pemimpin mempunyai karisma yang besar sehingga para karyawan merasa sungkan dengan pemimpin. Pemimpin UMKM sangat teliti dalam mengotrol out put yang dihasilkan oleh para karyawannya. Pada variabel organizational culture masing-masing dimensi memiliki korelasi yang tinggi pada dimensinya jika dibandingkan dengan koerelasinya pada indikator atau dimensi yang lain sehingga variabel organizational culture memiliki discriminant validity yang tinggi.

Tabel 4. Convergent validity dan cross loading teknologi informasi

\begin{tabular}{lcc}
\hline \multicolumn{1}{c}{ Keterangan } & $\begin{array}{c}\text { Convergent } \\
\text { validity }\end{array}$ & $\begin{array}{c}\text { Cross } \\
\text { loading }\end{array}$ \\
\hline $\begin{array}{l}\text { Organisasi menggunakan } \\
\text { teknologi informasi } \\
\text { (TI1) }\end{array}$ & 0.878130 & 0.878130 \\
$\begin{array}{l}\text { Organisasi menggunakan (pos, } \\
\text { kurir, telfon, fax, email, website, }\end{array}$ & 0.781419 & 0.781419 \\
$\begin{array}{l}\text { HP) untuk berkomunikasi (TI2) } \\
\text { Organisasi menggunkan komputer } \\
\text { untuk kegiatan sehari - hari (TI4) }\end{array}$ & 0.563086 & 0.563086 \\
$\begin{array}{l}\text { Organisasi memiliki system dalam } \\
\text { pengambilan keputusan yaitu } \\
\text { komputer, email, internet, dan } \\
\text { system evaluasi kinerja pembelian } \\
\text { (TI5) }\end{array}$ & 0.560590 & 0.560590 \\
$\begin{array}{l}\text { Menggunakan teknologi informasi } \\
\text { berdasarkan aktivitas (TI9) }\end{array}$ & 0.518303 & 0.518303 \\
$\begin{array}{l}\text { Teknologi informasi untuk } \\
\text { berkomunikasi dengan rekan } \\
\text { bisnis (TI10) }\end{array}$ & 0.645548 & 0.645548 \\
$\begin{array}{l}\text { Setelah menggunakan teknologi } \\
\text { informasi organisasi menjadi lebih } \\
\text { efektif (TI12) }\end{array}$ & 0.717949 & 0.717949 \\
\hline
\end{tabular}

Berdasarkan tabel 4 dapat diketahui bahwa indikator yang memiliki convergent validity dan cross loading tertinggi adalah TI 1.Media komunikasi yang banyak digunakan adalah telfon, handphone (BBM dan SMS), dan internet. Indikator yang memiliki convergent validity terendah adalah TI9. Penggunaan teknologi informasi sebagai media komunikasi disesuaikan dengan kebutuhan. Jika pemilik melakukan aktivitas komunikasi dengan rekan bisnis dan karyawan maka handphone merupakan media komunikasi yang selalu digunakan. Internet akan digunakan oleh pemilik jika ingin mencari inspirasi model-model 
terbaru. Pada variabel teknologi informasi masingmasing indikator memiliki korelasi yang tinggi pada indikatornya jika dibandingkan dengan korelasinya pada indikator atau dimensi yang lain sehingga variabel teknologi informasi memiliki discriminant validity yang tinggi.

\section{Analisis Composite Reability}

Tabel 5. Tabel Composite Reability

\begin{tabular}{lcccc}
\hline & AVE & $\begin{array}{c}\text { Composite } \\
\text { Reliability }\end{array}$ & R Square & $\begin{array}{c}\text { Cronbachs } \\
\text { Alpha }\end{array}$ \\
\hline LS & 0.476232 & 0.861981 & & 0.814131 \\
MCS & 0.513280 & 0.840157 & 0.472216 & 0.762254 \\
OC & 0.641331 & 0.914255 & 0.439016 & 0.886560 \\
TI & 0.459125 & 0.851807 & 0.134610 & 0.808286 \\
\hline
\end{tabular}

Berdasarkan tabel 5 dapat diketahui bahwa variabel LS dan TI tidak memiliki discriminant validity yang baik, sedangkan variabel MCS dan OC memiliki discriminant validity yang baik. Berdasarkan tabel 5 semua variabel memiliki composite reability diatas 0,8 yang berarti masing-maisng variabel dapat menjelaskan dengan baik keadaan yang sesungguhnya di lapangan. Berdasarkan tabel 5 MCS memiliki $\mathrm{R}^{2} 0,47$ yang berarti LS menggambarkan MCS sebesar $47 \%$, TI memiliki $\mathrm{R}^{2}$ sebesar 0.13 yang berarti LS dapat menggambarkan TI sebesar 13\%, OC memiliki $\mathrm{R}^{2} 0.43$ yang berarti LS dapat menggambarkan OC sebesar 43\%. Besarnya goodness of fit $\left(\mathrm{Q}^{2}\right)$ dapat dihitung dengan $1-((1-0.47) \times(1-0.43) \times$ $(1-0.13))=0.738$. Hal ini menunjukkan bahwa kemampuan model sebagai prediksi hubungan antara variabel atau antara konsep sebesar $73.8 \%$.

\section{Analisis Inner Model}

Tabel 6. Path Coefisien

\begin{tabular}{|c|c|c|c|c|}
\hline & $\begin{array}{l}\text { Original } \\
\text { Sample } \\
\text { (O) }\end{array}$ & $\begin{array}{c}\text { Standard } \\
\text { Deviation } \\
\text { (STDEV) }\end{array}$ & $\begin{array}{c}\text { T statistik } \\
\text { (|O/STERR|) }\end{array}$ & Keterangan \\
\hline $\begin{array}{l}\text { LS -> } \\
\text { MCS }\end{array}$ & -0.006597 & 0.153835 & 0.042886 & $\begin{array}{c}\text { Tidak } \\
\text { signifikan }\end{array}$ \\
\hline $\begin{array}{l}\text { LS -> } \\
\text { OC }\end{array}$ & 0.569344 & 0.115605 & 4.924913 & Signifikan \\
\hline $\begin{array}{l}\text { LS -> } \\
\text { TI }\end{array}$ & 0.366892 & 0.165079 & 2.222529 & Signifikan \\
\hline $\begin{array}{l}\text { OC -> } \\
\text { MCS }\end{array}$ & 0.387016 & 0.136403 & 2.837303 & Signifikan \\
\hline $\begin{array}{l}\text { TI -> } \\
\text { MCS }\end{array}$ & 0.438811 & 0.161587 & 2.715629 & Signifikan \\
\hline $\begin{array}{l}\text { TI -> } \\
\text { OC }\end{array}$ & 0.189231 & 0.138359 & 1.367683 & $\begin{array}{c}\text { Tidak } \\
\text { signifikan }\end{array}$ \\
\hline
\end{tabular}

Berdasarkan tabel 6 , dengan nilai t tabel sebesar 1,96 dapat diketahui bahwa LS tidak berpengaruh signifikan secara langsung dengan MCS. Hal ini dikarenakan pertama segala komunikasi untuk mengontrol jalannya usaha dilakukan dengan menggunakan bantuan teknologi informasi sebagai media komunikasi (telfon, BBM, dan SMS), kedua sistem kerja yang ada pada UMKM sektor garmen merupakan sistem kerja yang telah dilakukan secara berulang-ulang sehingga pemilik merasa tidak perlu melakukan kontrol secara langsung namun menggunakan teknologi informasi sebagai media komunikasi antara pemilik dengan karyawan, pemilik dengan rekan bisnis untuk mengontrol jalanya usaha tersebu. Ketiga, pemilik UMKM biasanya memiliki orang kepercayaan untuk mengawasi jalanya kegiatan bisnis. Saat pemilik ingin mengetahui kondisi usahanya akan bertanya kepada orang yang dipercayainya tersebut. Orang kepercayaan ini biasanya orang yang telah lama bekerja dengan pemilik dan memiliki hubungan yang baik. Oleh karena alasan tersebut leadership style tidak memiliki pengaruh secara langsung terhadap management control system. Berdasarkan tabel 6 dapat diketahui bahwa TI tidak berpengaruh signifikan terhadap OC. Hal ini dikarenakan pada UMKM meskipun mengunakan teknologi informasi sebagai media komunikasi, karyawan mengerjakan pekerjaannya di rumah masing-masing, sehingga komunikasi antar karyawan kurang begitu terjadi. Komunikasi terjadi sebagian besar terjadi antara pemilik usaha "juragan" dengan masing-masing karyawan, dan antara "juragan" dengan rekan bisnisnya. Komunikasi dilakukan dalam waktu yang singkat dan topik pembicaraan sebatas urusan pekerjaan. Pada UMKM adanya teknologi infomasi sebagai media komunikasi yang dapat mengintegrasikan satu sama lain belum ada, sehingga rasa berbagi dan menumbuhkan visi yang umum yang akan menjadi nilai budaya pada semua anggota UMKM sulit untuk diwujudkan.

\section{KESIMPULAN DAN REKOMENDASI}

Berdasarkan hasil penelitian dapat disimpulkan bahwa pada UMKM sektor garmen(a) leadership stlye memiliki pengaruh terhadap organizational culture (b) leadership style memiliki pengaruh terhadap penggunaan teknologi informasi (c) teknologi informasi sebagai media komunikasi yang digunakan dapat mempengaruhi management control system(d)leadership style tidak dapat mempengaruhi management control system secara langsung namun dapat mempengaruhi management control system dengan mediasi variabel teknologi informasi dan 
variabel organizational culture (e) penggunaan teknologi informasi sebagai media komunikasi tidak terbukti dapat mempengaruhi budaya organisasi (f) organizational culture memiliki pengaruh terhadap management control system.

\section{Keterbatasan Penelitian}

Untuk penelitian selanjutnya hendaknya diperluas pada UMKM secara keseluruhan; sampel responden yang digunakan lebih besar sehingga lebih dapat mencerminkan keadaan yang sebenarnya; lingkup wilayah penelitian hendaknya lebih luas; leadership style dilihat dari masing-masing sudut pandang transformational leadership dan transactional leadership, bukan dipandang sebagai satu kesatuan seperti dalam penelitian ini; melakukan identifikasi gaya kepemimpinan dan budaya organisasi yang dominan di UMKM sektor garmen.

\section{DAFTAR PUSTAKA}

Ali, Qomar dan ur Rehman, Manqoosh. 2011. Cultural Diagnosis; An Empirical Investigation of Cellular Industry of Pakistan. Asian Journal of Business Management 3(4);278-286.

Armesh, Hamed; Habibollah Salarzehi dan Baquer Kord. 2010. Management Control System. Interdisciplinary Journal of Contemporary Research in Business. Vol.2 No.6

Barrio, A.A. 2003. An Organizational Culture Assesment Using The Competing Value Framework; a Profile of State University Extension. Extension Journal, ISSN 1077-5315.

Bass, B. M. 1990. Bass \& Stogdill's Handbook of Leadership (3rd ed.). New York: The Free Press.

Bass, B.M dan Avolio, B.J. 1994. Improving Organizational Effevtiveness Through Transformational Leadership. Thousand Oaks; Sage Publication.

Bass, B.M dan Avolio, B.J. 1993. Transformational Leadership and Organizational Culture.Public Administration Quartely, 17(1), 112-121.

Bass, B.M. 1990. From Transactional to Transformational leadership; Learning to Share Vision. Organizational Dynamics, 18(3),19-31.

Bass, B.M. 1998. Transformational Leadership; Industrial, Military, and Educational Impact. Mahwah, N.j. Lawrance Erlbaum Associates.

Bass, B.M. Two. 1999. Decades of Research and Development in Transformational Leadership. European Journal of Work and Oranizational Psychology, 8(1), 9-32.
Bell, G. 1965. The Influence of Technological Components of Work Upon Management Control. Academy of Management Journal, Vol.8 No.2, pp 127-132.

Bruque, S. dan Moyano, J. 2007. Organizational determinant of information technology adoption and implementation in SMEs; The case of family and cooperative firm.Technovation, 275 (5),241-253

Cameron, K.S dan Quinn, R.E. 1999. Diagnosing and Changing Organizational Culture Based on the Competing Value Framework. Addison Wesley Longman, Inc.

Cameron, Kim dan Quinn, R. 2010. The Organizational Culture Assesment Instrument. OCAI Online.

Claver, Enrique; Llopis, Juan; Gonzales, M. Reyes dan Gaso, Jose L.The Performance of Information System Through Organizational Culture. Information Technology and People, Vo.14 No. 3, pp. 247-260.

Fauzi, hasan; Hussain, Mostaq M; Mahoney, Louis. 2012. Management Control system and Contextual in the Hospitality Industry.

Ghobakhloo, Morteza; Sabouri, Mohammad Sadegh; Hong, Tang Sai; dan Zulkifli, Norzima. 2011. Information Technology Adoption in Small and Medium Sized Enterprises; An Apprasial of Two Decades Literatur. Interdisciplinary Journal of Research in Bussines, Vol, 1 Issue.7, pp. 53-80.

Henri, J-F. (2006). Management control systems and strategy: A resource-based perspective. Accounting, Organizations and Society. vol. 31. no. 6. pp. 529-558.

Ismail, Tubagus; Wiyantoro, Lili Sugeng; Meutia; dan Muchlish, Munawar. 201. Strategy, Interactive Control System and National Culture; A Case Study of Batik Industry in Indonesia. International Congress on Interdisciplinary Business and Social Sciences. Procedia-Social and Behavioral Sciences 65 33-38.

Jansen,E Pieter. 2008. Change in Leadership Style, Management Control and Management Accounting: A Case Study of a Multi Outer Car Dealership.University of Groningen.

Koskiniemi, Toumas. 2009. Interplay of Control in a Cotemporary Organization. Helsinki School of Economic Department of Accounting and Finance.

Langfield-Smith, K. 1997. Management Control System and Strategy; A Critical Review, Accounting, Organization and Society, Vol.22, No.2, pp.207-232. 
Nguyen, T.U.H. 2009. Information technology adoption in SMEs an integrated framework. International Journal of Enterpreneurial Behaviour and Research, 15(2), 162-186.

Quinn, R.E dan Rohrbaugh, J. 1983. A Spatial Model of Effectiveness Criteria; Towards a Competing Value Approach to Organizational Analysis. Management Science,29(3),363-377.

Quinn, R.E. 1998. Beyond Rational Management, Mastering the Paradoxes and Competing Demands of High Performance.San Francisco; Jossey-Bass.

Salih, Hasan; Syarif, Abdelah; dan Ahmad, Ameeen. 2012. Impact of Information Technology on Management Control at Al Bahshir Hospital; A Case Study of Jordan. International journal of Bussiness and Management.

Schepers, Jeron; Wetzels, Martin; Ruyter, Ko de. 2005. Leadership Style in Technology Accep- tance; do Followers Practice What Leader Preach?.Managing Service Quality, Vol.15 No.6 pp 496-4529

Schimmoeller, Leon J. 2010. Leadership Style in Competing Organizational Culture. Ledership Review, Karvis Leadership Institute, Claremont McKenna College, Vol.10.

Sharma, Milind Kumar dan Bhagwat, Rajat. 2005. Practice of Information System Evidence from Select Indian SMEs.Journal of Manufacturing Technology Management, Vol.17 No.2, pp.199223.

Simon, Robert. 1995. Levers of Control; How Managers Use Innovative Control System to Drive Strategic Renewal. Havard.

Thong, J.Y. dan Yap, C.S. 1995. CEO Characteristic, Organizational Characteristic and Information Technology Adoption in Small Bussiness. Omega, 23(4), 429. 